\title{
SHADOW ECONOMY ESTIMATION METHODS: DIGITAL SHADOW ECONOMY ASSESSMENT ASPECT
}

\author{
Ligita Gasparèniené $\dot{e}^{1}$, Rita Remeikiene் $\dot{\mathbf{e}}^{2}$ \\ Department of Banking and Investment, Faculty of Economics and Finance Management, \\ Mykolas Romeris University, Ateities str. 20, LT 08303, Vilnius, Lithuania \\ E-mails: 'ligitagaspareniene@mruni.eu; ${ }^{2}$ rita.remeikiene@mruni.eu (corresponding author)
}

\begin{abstract}
This article is aimed at the ascertainment of whether the determinants of digital shadow economy are included in the methods of traditional shadow economy estimation. The results of the research have disclosed that the methods of shadow economy estimation consider general economic, monetary, money turnover, electricity and energy consumption, labour market, taxation, legal, and societal variables. However, the determinants of digital shadow economy are not included in the methods of shadow economy estimation, which not only impedes understanding of the real scopes of this phenomenon, but also complicates development of the measures aimed at digital shadow economy investigation and prevention.
\end{abstract}

Keywords: shadow economy, digital shadow economy, estimation methods, direct methods, indirect methods, models.

JEL Classification: E26; H26; K42; O17.

\section{Introduction}

Despite some scientific propositions that shadow economy it a natural element of economic and social life (Schneider et al. 2015), which emerges under the conditions of economic activity taxation and regulation (Zukauskas 2014), the problem of shadow economy remains the pressing topic in both discussions on economic policy and scientific research. The focus on the problem of shadow economy shows that the scopes of this phenomenon are considered unacceptably high and necessary to reduce.

Although following the Regulation No. $549 / 2013$ of the European Parliament and of the Council of 21 May 2013 on the European system of national and regional accounts in the European Union, there is no obligation to measure the nonobserved economy in the European system of national accounts, many users of statistics (e.g. economists, policy makers, tax administrators, representatives of law enforcement institutions, etc.) are interested in it. Hence, the variety of methodologies are developed to measure the scopes of shadow economy, at least approximately.

The results of estimations show that the scopes of shadow economy significantly vary for different countries. It is determined not only by differences in economic development of these countries, but also by a wide variety of the methods employed to estimate to size of shadow economy. According to Schneider and Buehn (2013: 2), "there are nowadays so many studies, which use different methods in order to estimate the size and development of the shadow economy, that it is quite difficult to judge the reliability of various methods." The problem of data variance calls for the necessity not only to estimate the size of shadow economy as a statistical record, but also to consider the complex of the factors that determine the total result.

Different forms of shadow economy, in particular shadow activities online that have gathered pace and generated a significant part of the overall value added over the last decade, are hardly considered while making estimations of the scope of shadow economy by different methodologies. According to Bossler and Holt (2012), lack of a universally recognised concept of digital shadow economy as well as absence of the methodologies purposefully developed to estimate its size are acknowledged as the key hindrances that complicate investigation and prevention of illegal businesses online.

Thus far, the studies on the issue of shadow economy estimation have covered the comparative analysis of different estimation methods (Williams 2006; Georgiou 2007; Schneider, Williams 2013; Schneider et al. 2015), causal variables (Buehn, Schneider 2012; Teobaldelli 2011; Teobaldelli, Schneider 2012) and results of the size of shadow economy obtained using different estimation methods (Pickhardt, Sarda Pons 2006; Schneider 
2007; Schneider, Buehn 2013; Schneider et al. 2015). Yet the problem of whether the determinants of digital shadow economy are included in the methods of shadow economy estimation has hardly been researched. Hence, it can be presumed that the methods applied for estimation of the size of traditional shadow economy may not reflect the size of digital shadow economy. For this reason, ascertainment of whether the determinants of digital shadow economy are included in the methods of traditional shadow economy estimation could contribute to improvement of the currently available estimation methods. What is more, it could serve for alleviation of the problem of digital shadow economy.

This article is aimed at the ascertainment of whether the determinants of digital shadow economy are included in the methods of traditional shadow economy estimation. For the fulfilment of the defined aim, the following objectives have been raised: 1) to analyse theoretical methodologies of traditional shadow economy estimation; 2) to present the methodology of the research; 3 ) to present the results of the research on whether the determinants of digital shadow economy are included in the methods of traditional shadow economy estimation. The methods of the research include logic and systematic analysis of scientific literature based in comparative and summary methods.

\section{Traditional shadow economy estimation methods: theoretical background}

The researchers who attempt to estimate the size of traditional shadow economy face a complicated task to evaluate the impact of various determinants on the total scope of shadow economy. According to Juskiene (2015), following the Regulation No. 549/2013 of the European Parliament and of the Council of 21 May 2013 on the European system of national and regional accounts in the European Union, there is no obligation to measure the non-observed economy in the European system of national accounts, i.e. the EU legislation does not require to measure the size of non-observed economy, but to ensure the exhaustiveness of estimated GDP and GNI. Hence, the authorized institutions in different countries as well as individual researchers are free for making the choice of the methods to measure the size of shadow economy.

With reference to provision 1.79 of the Regulation No. 549/2013 of the European Parliament and of the Council of 21 May 2013 on the European system of national and regional accounts in the European Union, illegal economic actions shall be considered as transactions when all units involved enter the actions by mutual agreement. Hence, purchases, sales or barters of illegal drugs or stolen property are considered as transactions, while thefts are not.

The analysis of the scientific literature has disclosed that three categories of methods - direct approaches, indirect approaches and latent variable models - are most widely used for estimation of the size of traditional shadow economy (see Table 1).

Direct approaches such as sample surveys (Williams et al. 2007; Williams, Nadin 2012), interviews (Fethi et al. 2006), expert evaluations (Augustinaitis et al. 2009; Williams, Nadin 2012), micro-surveys (Georgiou 2007) or compliance methods (Schneider, Buehn 2013) refer to microeconomic methods based on voluntary replies or tax auditing (Schneider, Buehn 2013). The main advantages of direct approach methods lie in their applicability to provide the detailed information

Table 1. Categories of the methods applied for estimation of the size of traditional shadow economy (Source: compiled by the authors)

\begin{tabular}{l|l|l|l}
\hline \multicolumn{1}{c|}{ Categories } & \multicolumn{1}{c|}{ Data type } & \multicolumn{1}{c}{ Methods } \\
\hline Direct approaches & Qualitative data & $\begin{array}{l}\text { Sample surveys, interviews, expert evaluations, micro-surveys of infor- } \\
\text { mal sector, compliance methods, in-depth audit }\end{array}$ \\
\hline Indirect approaches & Quantitative data & Monetary & $\begin{array}{l}\text { Denomination of bank notes, cash contribution ratio, } \\
\text { currency ratio/demand method, transaction method }\end{array}$ \\
\hline Indirect approaches & Quantitative data & $\begin{array}{l}\text { Income and } \\
\text { expenditure }\end{array}$ & $\begin{array}{l}\text { GDP discrepancies, income/expenditure discrepancies, } \\
\text { consumer expenditure (single equation and demand sys- } \\
\text { tem), national accounting aggregates }\end{array}$ \\
\cline { 2 - 4 } & & Non-monetary & $\begin{array}{l}\text { Ranking, electricity consumption method, detection- } \\
\text { controlled estimation, the number of small and medium } \\
\text { enterprises, employment (labour) discrepancies }\end{array}$ \\
\hline Latent variable models & Multiple data & SEM, DGE, MIMIC \\
\hline
\end{tabular}


about the structure of shadow economy (Schneider et al. 2015) and involve different economic subjects, i.e. households and business enterprises (Williams 2006). In addition, the methods of direct approach are considered to be cheap and simple to conduct (Georgiou 2007). Nevertheless, they are criticized for flaws or surveys (Schneider, Buehn 2013), unreliability of the collected data (a respondent may falsify the information, especially related to shadow activities, which are likely to be hidden) (Fethi et al. 2006; Williams, Nadin 2012), sensitivity of the results to the way questions are formulated (Schneider et al. 2015), applicability only for small-scale studies (Williams 2007; Herwartz et al. 2013), applicability for estimation of final rather intermediate demand (Herwartz et al. 2013). Considering advantages and disadvantages of direct approach methods, it can be stated that the results obtained while applying direct approach methods greatly depend on respondents' honesty and willingness to cooperate. Hence, the real size of shadow economy can be underestimated. To minimize the problem of data unreliability, structured interviews are recommended to be undertaken (Schneider, Buehn 2013).

Indirect or indicator approaches including monetary, income and expenditure, and nonmonetary methods (Williams et al. 2007; Georgiou 2007; Sookram et al. 2009; Schneider et al. 2015) refer to macroeconomic methods based on estimation and comparison of various economic and noneconomic indicators, starting with GDP and ending with the number of small and medium enterprises in the researched industry or country (Georgiou 2007). According to Schneider and Buehn (2013), the main advantage of the methods of indirect approach is that they cover the analysis of the indicators that contain information about the development of shadow economy over the time. However, with reference to the data of the report announced by the experts in OECD (2002) as well as the findings of some scientific studies (Renooy et al. 2004; Fethi et al. 2006; Williams 2006; Williams 2009; Williams 2010; Williams, Nadin 2012; Schneider, Buehn 2013 and others), the methods of indirect approach appeared as inaccurate, with limited application opportunities, determined by data disparities, providing crude and unreliable estimates, and leaning on discrepancies of the statistical data while comparing manufacture and consumption records.

If direct approaches lean on rather subjective evaluations, while indirect ones consider a single indicator to estimate the size of shadow economy, latent variable models such as SEM (Structural Equation Model) (Dell'Anno, Solomon 2008; Schneider et al. 2010) and MIMIC (Multiple Indicators Multiple Causes) (Georgiou 2007; Schneider, Buehn 2013; Schneider et al. 2015 and others) reflect the impact of the variety of markets (production, labour and money) on the size of shadow economy (Schneider, Buehn 2013), i.e. latent variable models consider multiple variables (dependent and independent) that determine the growth of shadow economy. This is treated as their main advantage in comparison to both direct and indirect approaches. In addition, latent variable models, in particular MIMIC, is considered to be adapted to constantly altering tax engineering and tax fraud (Syal 2013; Schneider et al. 2015). On the other hand, latent variable models are criticized for requirement of the new data for black market measurement as well as for the difficulties that occur while attempting to define the magnitude of measurement error (Schneider et al. 2010; Schneider et al. 2015). What is more, they are not recommended to use for statisticians since, with reference to Juskiene (2015), they fail to distinguish the causes of non-observed economy as the assumptions used are rather soft, and the probability of double counting (overestimation) is comparatively high.

Summarising, scientific literature offers a variety of the methodologies developed to estimate the size of traditional shadow economy. Different approaches lean on whether subjective evaluations (direct approaches) or consideration of particular indicators (indirect approach and latent variable models). Direct methods provide the opportunities to acquire the data on participation of physical and juridical entities in officially undeclared economics by employing sample methods and special statistical surveys. Indirect methods are based on comparison of various statistical indicators, and the identified discrepancies are explained by employing monetary, economic and social determinants. Finally, latent variable models enable to reveal the impact of production, labour and money markets on the overall size of shadow economy by employing multiple variables.

The further research will cover a comparative analysis of the variables incorporated in direct, indirect methods and latent variable models, the most commonly used for the research on traditional shadow economy. The comparative analysis will reveal whether the determinants of digital shadow economy are included in the methods of traditional shadow economy estimation. 


\section{Substantiation of the research methodology}

The analysis of accumulated knowledge on a particular topic (in this case - shadow economy estimation methodologies) requires systematic review and classification of the relevant scientific literature. The method of scientific literature analysis was selected for the research as it enables to concentrate on the topic and accommodates several data collection techniques such as literature review, library research and historical analysis. In addition, it enables to combine the results of both theoretical and empirical research obtained in previous scientific studies. Finally, the key benefit of scientific literature analysis is its contribution to disclosure of descriptive inferences that would be missed in typical statistical analyses.

Scientific literature review allowed to identify the methods that are employed for estimation of the size of shadow economy. The method of comparative analysis as well as application of the rules of logical interference enabled to establish the determinants (variables) of shadow economy that are included in different shadow economy estimation methods.

For the purpose of conducting this research, several databases with the large number of scientific journals on economics, engineering, management and IT were searched. The target search enabled to collect a substantial proportion of the material on shadow economy estimation methods within various studies.

The research was performed in the following stages: 1) after the comprehensive analysis of the scientific literature, the boundaries of the researched problem were identified; 2) theoretical methods of shadow economy estimation were identified; 3) new aspects of the research were found, i.e. it was disclosed whether the determinants of digital shadow economy are included in the methods of traditional shadow economy estimation.

\section{The results of the research}

The analysis of the scientific literature has revealed that direct methods the most commonly applied for the research of traditional shadow economy include sample surveys (Williams et al. 2007; Williams, Nadin 2012), interviews (Fethi et al. 2006; Augustinaitis et al. 2009; Williams, Nadin 2012), expert evaluations (Augustinaitis et al. 2009; Williams, Nadin 2012), micro-surveys (Georgio 2007) and in-depth audit (Schneider, Buehn 2013), while the most commonly applied indirect methods include evaluation of GDP discrepancies, transaction method, currency ratio method, electricity consumption method and employment (labour) discrepancies (Georgio 2007; Ardizzi et al. 2013; Herwartz et al. 2013). MIMIC method is recognised as the most commonly used model of latent variables (Schneider, Williams 2013; Buehn, Schneider 2012). Comparative analysis of the variables considered in the methods mentioned above has been presented in Table 2 .

As it canbe seen from Table 2, the methods of direct approach basically consider household (characteristic of shadow economy participants, shadow economy determinants, types of goods and services the most commonly traded in shadow economy, shadow economy channels), business (business income, expenditure, tax rate, the share of taxes in the total expenditure, tax return, electricity consumption quantities) and general economic (prognosticated total size of shadow economy as a percentage of GDP, prognosticated size of shadow economy in particular sectors or sector groups, sectors with the largest scopes of shadow economy) variables. European Commission also provides in-depth audits on countries compliance with the requirements of main legal acts, including exhaustiveness issues (Juskiene 2015).

The methods of indirect approach are based on evaluation of general economic indicators (national income and national expenditure balance, consumption rate, value added, imports, exports, prices, interest rate, proportion of wages and salaries in national income, income per capita, average tax rate, corporate profit and taxes on goods and services to GDP, the ratio of public social welfare expenditures to GDP, the sum on number of dependants over 14 years and of inactive earners, the ratio of the sum of paid personal income), general monetary indicators (velocity of money, currency demand), money turnover indicators (ratio of cash holdings to deposit accounts, the value of total bank transactions, the number of the issued credit and debit cards), electricity and energy consumption indicators (overall electricity consumption, electricity consumption in households per capita, real consumption of households without electricity consumption per capita, real price of consumption of $1 \mathrm{kWh}$ of residential electricity, relative frequency of months with the need of heating, the ratio of energy sources other than electric energy) and labour market indicators (total labour force rate, labour participation rate).

The latent variable, in particular MIMIC method considers the mixture of general economic (GDP per capita), taxation (share of direct taxation, 
Table 2. Comparative analysis of the variables considered in the most common methods of shadow economy estimation (Source: compiled by the authors)

\begin{tabular}{|c|c|c|}
\hline Approach & Method & Variables \\
\hline Direct & Sample survey & $\begin{array}{l}\text { Characteristics of shadow economy participants, shadow economy determi- } \\
\text { nants, types of goods and services the most commonly traded in shadow } \\
\text { economy }\end{array}$ \\
\hline Direct & Interview & $\begin{array}{l}\text { Characteristics of shadow economy participants, shadow economy determi- } \\
\text { nants, shadow economy channels }\end{array}$ \\
\hline Direct & Expert evaluation & $\begin{array}{l}\text { Prognosticated total size of shadow economy as a percentage of GDP, prog- } \\
\text { nosticated size of shadow economy in particular sectors or sector groups, } \\
\text { sectors with the largest scopes of shadow economy, characteristics of shadow } \\
\text { economy participants, types of goods and services the most commonly traded } \\
\text { in shadow economy }\end{array}$ \\
\hline Direct & Micro-survey & $\begin{array}{l}\text { Business income, expenditure, tax rate, the share of taxes in the total expendi- } \\
\text { ture, electricity consumption quantities }\end{array}$ \\
\hline Direct & In-depth audit & $\begin{array}{l}\text { Overall tax rate, the share of taxes in the total business and household ex- } \\
\text { penditure, tax return, national account exhaustiveness }\end{array}$ \\
\hline Indirect & GDP discrepancies & National income and national expenditure \\
\hline Indirect & Transaction method & Velocity of money, the value of total transactions, prices, official GNP \\
\hline Indirect & Currency ratio method & $\begin{array}{l}\text { Currency demand, proportion of wages and salaries in national income, in- } \\
\text { come per capita, interest rate (paid on savings deposit), ratio of cash holdings } \\
\text { to deposit accounts, average tax rate, the number of the issued credit and deb- } \\
\text { it cards as a substitute for cash }\end{array}$ \\
\hline Indirect & $\begin{array}{l}\text { Electricity consumption } \\
\text { method }\end{array}$ & $\begin{array}{l}\text { Electricity consumption, GDP (overall economic activity - official plus unof- } \\
\text { ficial) (Kaufmann, Kaliberda 1996); electricity consumption in households } \\
\text { per capita, real consumption of households without electricity consumption } \\
\text { per capita, real price of consumption of } 1 \mathrm{kWh} \text { of residential electricity, rela- } \\
\text { tive frequency of months with the need of heating, the ratio of energy sources } \\
\text { other than electric energy, the ration of the sum of paid personal income, cor- } \\
\text { porate profit and taxes on goods and services to GDP, the ratio of public so- } \\
\text { cial welfare expenditures to GDP, the sum on number of dependants over } 14 \\
\text { years and of inactive earners (Lacko 1998) }\end{array}$ \\
\hline Indirect & $\begin{array}{l}\text { Employment (labour) } \\
\text { discrepancies }\end{array}$ & Total labour force rate, labour participation rate \\
\hline Indirect & $\begin{array}{l}\text { National accounting } \\
\text { aggregates }\end{array}$ & $\begin{array}{l}\text { Gross output, value added, illegal transactions with tobacco, alcohol, drugs } \\
\text { and sexual services, production, imports, intermediate and final consumption, } \\
\text { exports }\end{array}$ \\
\hline $\begin{array}{l}\text { Latent } \\
\text { variable }\end{array}$ & MIMIC & $\begin{array}{l}\text { Share of direct taxation, share of indirect taxation and social security contri- } \\
\text { bution, state regulation, tax morale, unemployment quota, GDP per capita, } \\
\text { employment quota, average working time per week, change of local currency } \\
\text { per capita }\end{array}$ \\
\hline
\end{tabular}

share of indirect taxation and social security contribution), legal (state regulation), societal (tax morale), labour market (employment quota, unemployment quota, average working time per week) and monetary (change of local currency per capita) indicators.

The size of non-official economy is included in the estimations of GDP. These estimations cover the data which is not included in the official statistics not only because activities are illegal, but also for many other reasons, e.g. no obligation to provide the data is established or reliable data is not available. Hence, European Commission recom- mends to consider the following non-official data: the number of enterprises that operate as deliberately non-registered to evade tax paying, offenses (e.g. prostitution, illegal tobacco and drug trade), household activities that do not have to be registered by law or are not investigated, activities of the enterprises that deliberately provide incomplete or falsified data, the activities not accounted for other statistical reasons (e.g. incomplete, improperly prepared data).

According to Juskiene (2015), several pilot projects have been launched by Lithuanian Department of Statistics in the last decade aiming to 
investigate broadly and in depth the phenomenon of non-observed economy. The studies revealed the main domains of possible gaps (underestimation or overestimation of national account indicators), and allowed to establish the main data sources and methods to avoid those deficiencies. With reference to the above mentioned studies, Lithuanian Department of Statistics distinguishes the following types of non-exhaustiveness in their national accounts: N2 (producers deliberately not registering), N3 (producers not required to register), N4 (legal persons not surveyed), N6 (producer deliberately misreporting) and N7 (other statistical deficiencies). The types N3, N4 and N7 are considered as negligible and not referring to the breach of legislation or some other rules publicly established. The type N2 refers to illegal activities that are not significant, but special attention is paid to them in order to ensure harmonization of GNI at the EU level, while N6 - deliberately misreporting - is treated as the bulk of non-observed economy in Lithuanian national accounts. Intentionally, misreporting by registered units (N6) means that enterprises provide incorrect data in their reports to the statistical or tax authorities. They can underreport their income or over record their purchases.

The distortion of national accounts aggregates (Gross output, Intermediate consumption and Value added) takes place in both cases if the adjustment to the data reported by production units is not made. The adjustment factors used by national accountants are based on the results of the special survey conducted by the State Tax Inspectorate (STI) - gross output and intermediate consumption are adjusted in national accounts, and consequently the value added (and GDP) is adjusted by the kinds of economic activities and producer groups. Auditors of STI provide their opinion on possible share of misreported income in enterprises they inspected.

With reference to the recommendations of European Commission, 4 types of illegal activities have been considered since 2011: illegal transactions with tobacco, alcohol and drugs and sexual services (other types are allowed to include if they are significant in the particular country) (Juskiene 2015). The volumes of production and imports, collectively composing intermediate and final consumption, as well as the extent of exports are estimated and included into corresponding national account aggregates. Estimates are based on the information collected from the law-enforcement institutions and additional sources:

- State Border Guard Service under the Ministry of the Interior.
- Lithuanian Customs under The Ministry of Finance.

- Police Department under the Ministry of the Interior.

- the State Medicines Control Agency.

- mass media.

- surveys conducted by different organizations.

The size of non-observed economy in Lithuania is included into GDP and GNI estimates. Traditional shadow economy estimation methodologies are also applied for estimation of the scopes of unofficial employment in the country. Certainly, the scopes of unofficial employment might be estimated by applying the method of expert evaluation, i.e. by surveying competent professionals in the labour market (particularly in cases, when available statistical data is considered unreliable). However, estimations based on the same methodologies may prevent emergence of subjectivity while assessing final results. Nevertheless, such estimations are rather crude. What is more, it would be, in fact, extremely difficult to employ the data of the expert evaluation for the assessment of unofficial employment distribution by regions and economic activities. On the other hand, indicators of unofficial employment obtained by making statistical estimations would be more accurate in comparison to the results obtained from an expert evaluation.

Summarising, the methods of shadow economy estimation consider general economic, monetary, money turnover, electricity and energy consumption, labour market, taxation, legal, and societal variables. However, the determinants of digital shadow economy are not included in the methods of shadow economy estimation either in international or national methodologies. Hence, the methods of traditional shadow economy estimation do not reflect the share of digital shadow economy in the overall size of shadow economy.

\section{Conclusions}

Scientific literature offers a variety of the methodologies developed to estimate the size of traditional shadow economy. Different approaches lean on whether subjective evaluations (direct approaches) or consideration of particular indicators (indirect approach and latent variable models). Direct methods provide the opportunities to acquire the data on participation of physical and juridical entities in officially undeclared economics by employing sample methods and special statistical surveys. Indirect methods are based on comparison of vari- 
ous statistical indicators, and the identified discrepancies are explained by employing monetary, economic and social determinants. Finally, latent variable models enable to reveal the impact of production, labour and money markets on the overall size of shadow economy by employing multiple variables.

The results of the research have disclosed that the methods of direct approach of shadow economy estimation basically consider household, business and general economic variables; the methods of indirect approach are based on evaluation of general economic, general monetary, money turnover, electricity and energy consumption and labour market; latent variable methods consider the mixture of general economic, taxation, legal, societal, labour market and monetary indicators. The size of non-observed economy in Lithuania is included into GDP and GNI estimates. However, the determinants of digital shadow economy are not included in the methods of traditional shadow economy estimation, which not only impedes understanding of the real scopes of this phenomenon, but also complicates development of the measures aimed at digital shadow economy investigation and prevention.

\section{Discussion}

It should be noted that estimations of shadow economy are often funded by public institutions due to high costs incurred, particularly in cases when direst research methods are employed. In addition, the size of shadow economy can be estimated by calculating the difference between total declared income and the income measured during the optional inspection. In this respect, tax audit that enables to estimate the scopes of undeclared taxable income is particularly efficient. Hence, it could be employed for estimation of the share of digital shadow economy in the total scope of shadow economy in a country or a sector. However, following this method, selection of entities to be inspected is based only on tax declarations submitted by taxpayers. This way, research samples are not random and cannot accurately reflect the overall situation. Moreover, estimations based on tax audit reflect only that share of shadow economy income which is disclosed by authorised public officers.

A significant disadvantage of direct and indirect shadow economy estimation methods is that they do not reflect all types of shadow activities (including the ones performed in digital space). Also, they represent only annual figures, which burdens estimation of the real size of shadow economy in the long term.

\section{Funding}

This work was supported by the Research Council of Lithuania [grant number MIP-15642].

\section{Disclosure statement}

The authors declare that they do not have any competing financial, professional, or personal interests from other parties.

\section{References}

Ardizzi, G.; Petraglia, C.; Piacenza, M.; Turati, G. 2013. Measuring the underground economy with the currency demand approach: a reinterpretation of the methodology, with an application to Italy, Review of Income and Wealth 60(4): 447-772. http://doi.dx.org/10.1111/roiw.12019

Augustinaitis, A.; Rudzkiene, V.; Petrauskas, R. A.; Dagyte, I.; Martinaityte, E.; Leichteris, E.; Malinauskiene, E.; Visnevska, V.; Zilioniene, I. 2009. Lietuvos e.valdzios gaires: ateities izvalgu tyrimas. Mykolas Romeris University [online], [cited 10 February 2016]. Available from Internet: http://ebooks.mruni.eu/product/lietuvos-evaldiosgairs-ateities-valg-tyrimas25169\#sthash. SWyBMnuZ.dpuf

Bossler, A. M.; Holt, T. H. 2012. Patrol officers' perceived role in responding to cybercrime, Policing: An International Journal of Police Strategies \& Management 35(1): 165-181. http://dx.doi.org/10.1108/13639511211215504

Buehn, A.; Schneider, F. 2012. Shadow economies around the world: novel insights, accepted knowledge, and new estimates, International Tax and Public Finance 19: 139-171. http://dx.doi.org/10.1007/s10797-011-9187-7

Dell'Anno, R.; Solomon, O. H. 2008. Shadow economy and unemployment rate in USA: is there a structural relationship? An empirical analysis, Applied Economics 40(19): 2537-2555. http://dx.doi.org/10.1080/00036840600970195

European Parliament and the Council. 2013. Regulation No. 549/2013 on the European system of national and regional accounts in the European Union. Official Journal of the European Union 174 [online], [cited 15 January 2016]. Available from Internet: http://eur-lex.europa.eu/legal-ctent/EN/TXT/PDF/? uri=uriserv:OJ.L_.2013.174.01.0001.01.ENG

Fethi, M. D.; Fethi, S.; Katircioglu, S. T. 2006. Estimating the size of the Cypriot underground economy. A comparison with European Experience, International Journal of Manpower 27(6): 515-534. http://dx.doi.org/10.1108/01437720610690464 
Georgiou, G. M. 2007. Measuring the size of the informal economy: a critical review. Central Bank of Cyprus [online], [cited 15 January 2016]. Available from Internet: http://www.centralbank.gov. cy/media/pdf/npwpe_no1_052007__.pdf

Herwartz, H.; Tafenau, E.; Schneider, F. 2013. One share fits all? Regional variations in the extent of the shadow economy in Europe, Regional Studies 49(9): 1575-1587. http://doi.dx.org/10.1080/00343404.2013.848034

Juskiene, G. 2015. Overview of the methods used to ensure exhaustiveness the national accounts of Lithuania. Lithuanian Department of Statistics [online], [cited 01 March 2016]. Available from Internet: http://www.oecd.org/std/na/2069700.pdf

Kaufmann, D.; Kaliberda, A. 1996. Integrating the unofficial economy into the dynamics of post socialist economies: a framework of analyses and evidence, Policy Research Working Paper Series 1691: 63-81.

Lackó, M. 1998. The hidden economies of visegrad countries in international comparison: a household electricity approach, Chapter 6, in L. Halpern, C. Wyplosz (Eds.). Hungary: towards a market economy. Cambridge: Cambridge University Press.

Organization for Economic Co-Operation and Development 2002. Measuring the non-observed economy. OECD Statistics [online], [cited 01 March 2016]. Available from Internet: http://www.oecd.org/std/na/1963116.pdf

Pickhardt, M.; Sardà Pons, J. 2006. Size and scope of the underground economy in Germany, Applied Economics 38(4): 1707-1713. http://dx.doi.org/10.1080/00036840500426868

Renooy, P.; Ivarsson, S.; van der Wusten-Gritsai, O.; Meijer, R. 2004. Undeclared work in an enlarged union: an analysis of shadow work - an in-depth study of specific items. European Commission [online], [cited 28 February 2016]. Available from Internet: http://ec.europa.eu/social/BlobServlet? docId $=2652$ \&langId $=$ en

Schneider, F. 2007. Shadow economies and corruption all over the world: new estimates for 145 countries [online], [cited 28 Februaray 2016]. Available from Internet: http://www.economicsejournal. org/economics/journalarticles/2007-9/version_1

Schneider, F.; Buehn, A. 2013. Estimating the size of the shadow economy: methods, problems and open questions. CESIFO [online], [cited 01 March 2016]. Available from Internet:

http://www.economics.jku.at/papers/2013/wp1320.pdf

Schneider, F.; Buehn, A.; Montenegro, C. 2010. New estimates for the shadow economies all over the world, International Economic Journal 24(4): 443-461. http://dx.doi.org/10.1080/10168737.2010.525974

Schneider, F.; Raczkowski, K.; Mróz, B. 2015. Shadow economy and tax evasion in the EU, Journal of Money Laundering Control 18(1): 34-51. http://dx.doi.org/10.1108/JMLC-09-2014-0027
Schneider, F.; Williams, C. C. 2013. The shadow economy. The Institute of Economic Affairs [online], [cited 01 March 2016]. Available from Internet: http://www.iea.org.uk/sites/default/files/publicatio ns/files/IEA\%20Shadow\%20Economy\%20web\%2 0rev\%207.6.13.pdf

Sookram, S.; Watson, P. K.; Schneider, F. 2009. Characteristics of households in the informal sector of an emerging economy, Applied Economics 41: 3545-3559. http://dx.doi.org/10.1080/00036840701493733

Syal, R. 2013. UK's tax gap rises by \&1bn to £35bn. The Guardian [online], [cited 15 January 2016]. Available from Internet:

http://www.theguardian.com/politics/2013/oct/11/u k-tax-gap-rises-hmrc-avoidance-nonpayment

Teobaldelli, D. 2011. Federalism and the shadow economy, Public Choice 146(3): 269-269. http://dx.doi.org/10.1007/s11127-009-9590-0

Teobaldelli, D.; Schneider, F. 2012. Beyond the veil of ignorance: the influence of direct democracy on the shadow economy. CESIFO [online], [cited 15 January 2016]. Available from Internet: http://www.econ.jku.at/members/Schneider/files/p ublications/2012/Teobaldelli.pdf

Williams, C. C. 2006. The Hidden enterprise culture: entrepreneurship and the shadow economy. $1^{\text {st }} \mathrm{ed}$. Cheltenham: Edward Elgar.

http://dx.doi.org/10.4337/9781847201881

Williams, C. C. 2007. Small business and the informal economy: evidence from the UK, International Journal of Entrepreneurial Behaviour \& Research 13(6): 349-366. http://dx.doi.org/10.1108/13552550710829160

Williams, C. C. 2009. Rationales for outsourcing domestic services to off-the-books workers, Journal of Economic Studies 36(4): 343-354. http://dx.doi.org/10.1108/01443580910973565

Williams, C. C. 2010. Out of the shadows: explaining the undeclared economy in Baltic countries, Journal of Baltic Studies 41(1): 3-22.

http://dx.doi.org/10.1080/01629770903525282

Williams, C. C.; Nadin, S. 2012. Tackling entrepreneurship in the informal economy: evaluating the policy options, Journal of Entrepreneurship and Public Policy 1(2): 111-124. http://dx.doi.org/10.1108/20452101211261408

Williams, C. C.; Round, J.; Rodgers, P. 2007. Beyond the formal/informal economy binary hierarchy, International Journal of Social Economics 34(6): 402-414. http://dx.doi.org/10.1108/03068290710751812

Zukauskas, V. 2014. Lietuvos seseline ekonomika. Lithuanian Free Market Institute. Available from Internet: http://files.lrinka.lt/Seseline_ekonomika/LSE3.pdf 